\title{
POLICY OF SMALL AND MEDIUM-SIZED ENTERPRISES IN CHINA
}

\begin{abstract}
This study is a general review of the SME sector in China. It contains criteria and definition of Chinese companies, brings special attention to traditional culture based on Confucianism, which influences the management of SME. The article also traces the SME sector reforms that have been carried out since 2000, as well as programs aimed at supporting the SME sector in China.
\end{abstract}

Ke y w ords: SME; China.

Klasyfikacja JEL: O20; O53.

\section{INTRODUCTION}

Since the process of liberalization launched in 1978, Chinese market is actively creating conditions for the development of private enterprise. The possibility of Chinese companies to cooperate with foreign investors made a positive impact on this process. Since the establishment of the PRC in 1949, private property due to ideological and political reasons was banned. In 1998, before the PRC became member of WTO, private property was recorded into the Chinese Constitution and was granted with

* Adres do korespondencji: Uniwersytet Mikołaja Kopernika w Toruniu, Wydział Nauk Ekonomicznych i Zarządzania, Katedra Inwestycji i Nieruchomości, ul. Gagarina 13, 87-100 Toruń, e-mail: malgorzata.powiertowska@gmail.com. 
the same rights as state property. During the transition period connected with membership in the WTO, Chinese state-owned companies did not undergo privatization and, instead, there were introduced reforms to develop the private sector ${ }^{1}$.

Small and medium-sized enterprises in China are mostly private companies. Five major Chinese companies, are largely state-owned public companies $^{2}$.

Development of small and medium-sized enterprises are increasingly contributing to the economic growth of China. SME account for over $99 \%$ of all Chinese enterprises with the output value of at least $60 \%$ of the gross domestic product of this country, generating over $82 \%$ of working places in China. SME clusters significantly increase the global competitiveness of SMEs, create and disseminate innovation and distribution on a large scale $^{3}$.

\section{CRITERIA FOR SME MEMBERSHIP IN CHINA}

Definition and criteria of belonging to SMEs sector in China were adjusted four times from 1949 to 2003 . New standards for small and medium-sized enterprises have been published for the relevant government agencies with the approval of the State Council. The standards are applied to government labor statistics and replace the old standards of classification, entered into force in 1988. They replace also additional standards published in 1992. Based on the new regulations, small and medium-sized industrial enterprises in China are defined as employing up to 2,000 people with annual income not exceeding 300 million Yuan $^{4}$, the total assets not exceeding 400 million RMB. Although the definition of SME in China is quite complex and contains relatively large companies compared to standards in other countries, in the scale of Chinese industry these companies are still relatively small [Cunningham, 2011, s. 40].

1 http://www.psz.pl/index.php?option=com_content\&task=view\&id=40421 [25.04.2014].

2 Ibidem

3 http://www.eria.org/SME\%20Development\%20in\%20China_A $\% 20$ Policy $\% 20$ Perspective\%20on\%20SME\%20Industrial\%20Clustering.pdf [25.04.2014].

4 Yuan, RMB - the official name of Chinese currency 
In contrast to the Polish and the European Union, the Chinese criteria defining and describing the SME sector are still under construction ${ }^{5}$. Standards of PRC enterprises differ from European standards in numbers of employees and value of annual revenue. Large enterprises are generally considered to be those that employ more than 1,000 employees, the average in the range from 300 to 999 employees, with annual income not exceeding three hundred million Yuan; small - 20 to 299 people; and micro - less than 20 people $^{6}$. The exception is micro-enterprise engaged in the management of fixed assets, which could employ up to 100 people ${ }^{7}$, generating annual revenues of not more than three million Yuan ${ }^{8}$.

The Chinese criteria are very diverse and limit values are dependent on the particular brunch. There exist two criteria: financial and employment. Telecommunication companies are among those attributed to the high threshold to employ more than 2000 people, or after crossing the border income and assets. In the transport and heavy industry the employment threshold is set at 1,000 people; in commercial enterprises and logistics 200 people. In industries such as agriculture, fisheries, forestry, architecture, construction and fixed assets management, the employment criteria are not provided and only the financial criteria is take into account. For other industries it is more than 300 people. Revenues of large enterprises oscillate between 50 million Yuan to 1.2 billion Yuan. In architecture and construction - more than 800 million Yuan, in financial services 1.2 billion Yuan, in heavy industry more than 400 million Yuan, the average income is between 200 and 300 million Yuan'.

Medium-sized enterprises are those that employ less than 2,000 people with annual income not exceeding 300 million Yuan and total assets not exceeding 400 million Yuan ${ }^{10}$. The SMEs in China are quantified, but they are also classified for administrative purposes. The SMEs generally can be divided into 2 broad categories into rural and urban areas. Rural cover

5 http://www.obserwatorfinansowy.pl/forma/rotator/chiny-small-business-przedsiebiorcy-rozwoj/ [25.04.2014].

6 http://www.gochina.gov.pl/files/?id_plik=194 [25.04.2014].

7 http://www.wiadomosci24.pl/artykul/nowa_klasyfikacja_wielkosci_ przedsiebiorstw_w_chinach_204886.html [25.04.2014].

8 http://www.obserwatorfinansowy.pl/forma/rotator/chiny-small-business-przedsiebiorcy-rozwoj/ [25.04.2014].

9 http://www.wiadomosci24.pl/artykul/nowa_klasyfikacja_wielkosci_ przedsiebiorstw_w_chinach_204886.html [25.04.2014].

10 L. X. Cunningham, SMEs as motor of growth... s. 40. 
almost all towns and rural businesses mainly of social ownership (TVE $=$ Town and Village Enterprises), and all rural private enterprises and acting on their own account ( $\mathrm{PE}=$ Private Enterprises). Municipal SMEs include small and medium-sized state-owned enterprises ( $\mathrm{SOE}=$ State Owned Enterprises), municipal cooperative enterprises $(\mathrm{COE}=$ collectively-Owned Enterprises), urban private businesses and acting on their own account (PE $=$ Private Enterprises) and other forms of property (OE - Other Enterprises), which compass companies including cooperative units, joint ownership units, limited liability companies, limited capital. As the number of small and medium-sized state-owned enterprises is relatively small, most SMEs in China are private companies (PE), cooperative (COE), companies from small towns and rural areas (TVE), self-employed and others (OE) [Cunningham, 2011, s. 40].

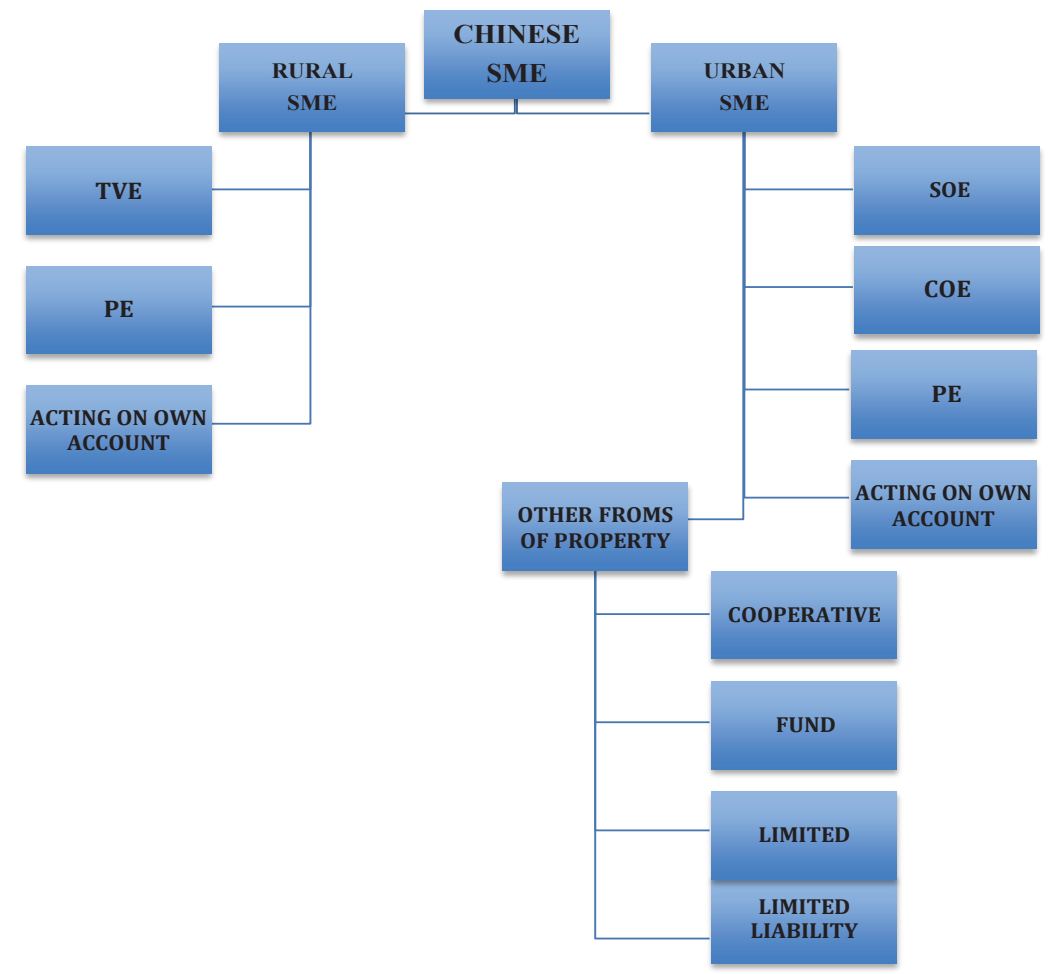

Chart 1. Classification of Chinese SMEs by region of registration.

Source: L. X. Cunningham, SMEs as mot or of growth: A review of China's SMEs development in thirty years (1978-2008), [w:] Human Systems Management, nr 30, 2011, s. 43. 
Micro-enterprises in China mostly elude any statistics, they often operate semi-legally. They are not objected to some specific control. Services provided are purely contractual price and the buyer does not receive any bill or receipt. Micro business can be seen everywhere, especially these are small eateries, grocery stores, convenience stores, laundries, barbershops and beauty, etc. Micro-enterprises operate in homes, garages, basements, booths, pavilions and outdoors ${ }^{11}$.

\section{TRADITIONAL CULTURE IN CHINESE SMES}

The management of small and medium-sized enterprises is influenced significantly by cultural and institutional factors. Confucianism played a key role in the history of China. It requires absolute respect for traditions based on exact hierarchical ranking system, which is known as the five duties [Cunningham, 2011, s. 48].: the subordinate should submit to his ruler, son should respect and submit to his father, wife to her husband, younger brother to the elder, friends to each other. The oldest member of the family should be respected by the rest of the family. It is the duty of family is to respect the ruler [Cunningham, 2011, s. 49]. Knowledge of economic or any other has a secondary meaning ${ }^{12}$. Confucianism formed a number of principles of human relations, such as relations between family members and between the people and their rulers. A special role in business deals plays guanxi, which can be treated as a network of relationships and connections. It is a "long-term personal relationship between two people, within which one of the participants is able to persuade the other to favorable treatment or services"13. It is a network of personal contacts, which is activated in order to fulfill something. The easiest way to visualize it in one sentence: "It does not matter what you know, it's important whom, you know"14. Relationships of this type are non-transferable and have personal character, it enforces certain behaviors and commitment. Guanxi does not function in family relationships, friendships and relations between employ-


iebiorcy-rozwoj/ [25.04.2014].

12 http://pl.wikipedia.org/wiki/Konfucjanizm [25.04.2014].

13 http://mfiles.pl/pl/index.php/Quanxi [25.04.2014].

14 Ibidem 
ers and employees ${ }^{15}$. Guanxi personal connections facilitate the development of SMEs, develop business networks [Cunningham, 2011, s. 49]. Cultural factors, strong relational connections and good neighborly residents can act as motivators for employees and inspire their inner enthusiasm [Cunningham, 2011, s. 49]. Traditions and cultural values, adopted ethics and morality of Confucian constitute a challenge for SMEs, while the law has a secondary role. Integration of SMEs in the global economy makes them to adapt to the WTO rules. The situation in which SMEs need to adapt to comply with the law is difficult because of the traditional moral codes and paying attention to the mood. Despite the modern Western influences such as consumerism, the basis of thinking and behavior is Confucian ethics [Cunningham, 2011, s. 50].

\section{WAYS TO SUPPORT THE DEVELOPMENT OF SMES IN CHINA}

The Chinese government has taken a number of steps to support SMEs. Chinese Council of Ministers stated that they want to protect the interests of the SME sector and therefore intend to strengthen government support for small and medium-sized enterprises. To this end, the authorities intend to carry out necessary reforms in key sectors of the domestic industry and lower the threshold of market access for small and medium-sized enterprises, as well as create a more fair and open competition for SMEs. The government intends to defer to small and medium-sized enterprises in difficulties with a year payment period to fund of social insurance to relieve them financially. To optimize the mechanism of public procurement, the SME's contracts will be increased ${ }^{16}$.

According to the strategy, the Chinese government supports all kinds of companies, especially small and medium-sized enterprises [Cunningham, 2011, s. 43] To oversee SMEs in China there were designated four administrative departments. These are: the National Development and Reform Commission, China's SME Coordination Center of International Cooperation, the China Association of SMEs and local departments of SMEs

15 Ibidem

16 http://www.bigchina.pl/printer/article/news/3062 [25.04.2014]. 
in each of the provinces ${ }^{17}$. In 2000 there was formed Chinese Working Group for Promotion of SME Development, created under the aegis of the Government Commission on Trade and Economics. In 2001, China joined the WTO (World Trade Organisation). In 2003, they adopted plans that require the promotion and equal treatment and equal opportunities for SMEs [Cunningham, 2011, s. 43]. According to these guidelines, the government seeks to protect legitimate investments of SMEs and investors, and capital gains from their investment. Governmental departments are to protect the rights of small and medium-sized enterprises, their rights to fair competition and fair trade. In addition, the law provided the basis for state aid for SMEs ${ }^{18}$. In 2005 it issued a document entitled "The State Council for Encourage, Support and Guidance in Development of Private and Other Non-Public Economies" in order to facilitate market access for non-public enterprises, providing them with appropriate wide space for development [Cunningham, 2011, s. 43]. In 2006 it created a project of growth for SMEs. Its aim to build a system of policies and regulations for SMEs by:

- supporting social services system;

- facilitating structural adjustment;

- maintaining reforms;

- strengthening training;

- improving the innovative capacity;

- solving financial difficulties arising from the activity;

- encouraging business expansion through foreign investment;

- improving the overall supervision ${ }^{19}$.

Also they have been adopted by government regulations and promotional activities to further support of SMEs. These include the following:

- financing the development of SME - there was created a fund to support SME; introduced tax breaks and subsidies for SME; increased requirements of financial institutions to increase financing in the form of loans and direct financial channels, seeks to create a SME credit guarantee;

17 http://www.eria.org/SME\%20Development\%20in\%20China_A\%20Policy\%20 Perspective\%20on\%20SME\%20Industrial\%20Clustering.pdf s. 43.

18 http://www.eria.org/SME\%20Development $\% 20$ in $\% 20$ China_A $\% 20$ Policy $\% 20$ Perspective\%20on\%20SME\%20Industrial\%20Clustering.pdf... s. $4 \overline{3}$.

19 http://www.eria.org/SME\%20Development $\% 20$ in $\% 20$ China_A $\% 20$ Policy $\% 20$ Perspective\%20on\%20SME\%20Industrial\%20Clustering.pdf... s. $4 \overline{4}$. 
- the funding of SME sector - the SMEs are encouraged to employ the required number of disabled people; the activities in the impoverished regions and economically underdeveloped areas or companies failing to meet the state requirement of employing an adequate number of workers - all they may rely on the exemption from income tax and tax breaks;

- access to the SMEmarket - for to improve market access, SME can count on the support of the government through increasing their skills under condition that they are approved by the government: the government requirement are to implement in a diligent industrial policy of the nation, compliance with the planning of industrial and particularly those concerning market access. The selected SMEs are provided with services and technologies, while public procurement system tends to favor the services and products produced by SMEs, where rules and laws restrict access to non-public enterprises; the relevant institutions have to make adjustments recipes for the benefit of SMEs; the government encourages SMEs to invest in foreign markets through the enforcement of financial rules through which they can rely on the privilege of imports and exports;

- cooperation with other companies - the state promotes mergers and acquisitions among SMEs, specialization, reorganization, use of resources in an optimal manner and coordination between SMEs; in order to strive for market expansion it can implement developed material supply, technological innovation, production, sales;

- effective supervision of SMEs - the government is trying to improve the system of management of SMEs, moving towards standardization of fees charged by public institutions and relevant organizations not to become too heavy a burden;

- the improvement of social services for SMEs - the government is trying to develop organizations aimed at providing services such as social brokerage in order to support particular projects, enhances political support, supports training for employees of companies, develops services for science and technological innovation, supports creation of credit system for entrepreneurs seeking to access domestic and foreign markets ${ }^{20}$.

In 2009 in Shenzhen Stock Exchange index there was launched "ChiNext" for small and medium-sized enterprises that were unable to

20 Ibidem, s. 44-46. 
meet the stringent criteria through which they could be admitted to trading on the main market. This applies to companies operating in industries with most advanced technologies that show great potential ${ }^{21}$. Chinese small and medium-sized enterprises have trouble getting financing through bank loans because banks are reluctant to lend to this sector, since this sector is burdened with high risk ${ }^{22}$. The market of Shenzhen Stock Exchange has become very popular among small and medium-sized enterprises, as well as among investors and it is an easy place to raise capita ${ }^{23}$.

In 2012, in the province of Wenzhou there was launched a pilot program to support SMEs through lending, which in the future may be the regulator for the SME sector. Wenzhou appointed Lending Center (WLC), the first institution designed to inform, advise and regulate matters of private loans that will be granted on the basis of civil law contracts. WLC has the task of promoting uniform standards for lending, risk analysis, curbing the illicit financing and to create safe law. WLC requires the submission of applications, so that one can confirm bank transfers between the borrower and the lender. It also intends to control standards, which companies must observe. These are:

- the number of entities in operation - to eliminate the pyramid schemes and illegal financing - one valid lender and one valid borrower;

- interest rates - to avoid usury, uniform civil interest rates are established in compliance with state law for borrowers and lenders;

- disclosure of information - to disclose fully and general information on loans and advances for to provide access to a list of institutions that can support such as law firms or consulting, etc .;

- responsibility - in the absence of the loan, one does not take responsibility ${ }^{24}$.

Reforms of Chinese banking system bases on the following five principles:

The financial sector has to be consistent for micro, small and mediumsized enterprises;

\footnotetext{
${ }^{21}$ http://www.szse.cn/main/en/ChiNext/aboutchinext/ [25.04.2014].

22 http://www.obserwatorfinansowy.pl/tematyka/rynki-finansowe/chinska-gielda-malych-firm-weszla-w-nowy-etap/ [25.04.2014].

23 http://www.obserwatorfinansowy.pl/tematyka/rynki-finansowe/rynek-pozagieldowy-ma-byc-w-chinach-miejscem-latwego-pozyskiwania-kapitalu/ [25.04.2014].

24 https://www.obserwatorfinansowy.pl/tematyka/bankowosc/chiny-lichwiarze-traca-grunt-a-banki-monopol/ [25.04.2014].
} 
the structures of the shares in the banks compared with private ownership to state ownership, the smallest share of the state (government) in banks China is $51 \%$. Experts suggest leaving this limit only for state-owned banks, while for non-state, they propose to abolish or reduce the border;

the division of operational and advisory functions requires separation of activities of retail banks from investment activities. Within a bank there cannot coexist these two functions. It regards domestic and foreign banks. For the finance and banking sector control there exist four Chinese institutions:

- People's Bank of China

- Chinese Commission for Banking Supervision

- Chinese Capital Supervisory Commission

- Chinese Insurance Regulatory Commission;

- there were developed special plans in case of fall of several or one Chinese bank;

- lending activity from parabanks should subject to special regulations ${ }^{25}$.

\section{CONCLUSION}

The SME sector in China can count on the increasing government support. For several years, the Chinese government supports SMEs through various reforms. Since the transformation of the Chinese economy, SMEs took on increasing importance for the economy. Most of the companies created special economic zones for SMEs, which largely determine the country's economic activity.

\section{BIBLIOGRAPHY}

Cunningham L. X., (2011), SMEs as motor of growth: A review of China's SMEs development in thirty years (1978-2008), "Human Systems Management", nr 30.

http://www.szse.cn/main/en/ChiNext/aboutchinext/

http://www.obserwatorfinansowy.pl/tematyka/rynki-finansowe/chinska-gieldamalych-firm-weszla-w-nowy-etap/

25 Ibidem 
http://www.obserwatorfinansowy.p1/tematyka/rynki-finansowe/rynek-pozagieldowy-ma-byc-w-chinach-miejscem-latwego-pozyskiwania-kapitalu/

https://www.obserwatorfinansowy.pl/tematyka/bankowosc/chiny-lichwiarze-traca-grunt-a-banki-monopol/

http://www.obserwatorfinansowy.pl/forma/rotator/chiny-small-businessprzedsiebiorcy-rozwoj/

http://www.eria.org/SME\%20Development\%20in\%20China_A\%20Policy\%20 Perspective\%20on\%20SME\%20Industrial\%20Clustering.pdf

http://www.bigchina.pl/printer/article/news/3062

http://www.gochina.gov.pl/files/?id_plik=194

http://mfiles.pl/pl/index.php/Quanxi

http://www.psz.pl/index.php?option=com_content\&task=view\&id=40421

http://pl.wikipedia.org/wiki/Konfucjanizm

http://www.wiadomosci24.pl/artykul/nowa_klasyfikacja_wielkosci_ przedsiebiorstw_w_chinach_204886.html

\section{POLITYKA WOBEC SEKTORA MŚP W CHINACH}

Streszczenie: Niniejsze opracowanie zostało poświęcone zaprezentowaniu sektora MŚP w Chinach. Przedstawione zostały kryteria i definicja przedsiębiorstw chińskich. Uwaga została zwrócona na kulturę tradycyjną opierającą się na konfucjanizmie, który wpływa na zarządzanie MŚP. Przedstawione zostały reformy przeprowadzone wobec sektora MŚP od 2000 roku oraz programy mające na celu wspieranie sektora MŚP.

Slowa kluczowe: MŚP; Chiny. 